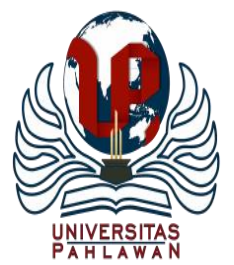

Edukatif : Jurnal Ilmu Pendidikan Volume 3 Nomor 5 Tahun 2021 Halm 2362 - 2370

EDUKATIF: JURNAL ILMU PENDIDIKAN

Research \& Learning in Education

https://edukatif.org/index.php/edukatif/index

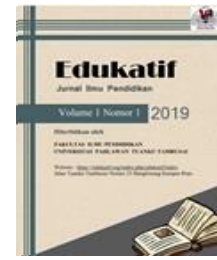

\title{
Keefektifan Metode SQ3R dalam Pembelajaran Membaca Pemahaman Teks Fiksi di Masa Pandemi Covid-19 pada Siswa SMP
}

\author{
Rika Afiana $^{1 凶}$, Wienike Dinar Pratiwi², Een Nurhasanah ${ }^{3}$ \\ Universtas Singaperbangsa Karawang, Indonesia ${ }^{1,2,3}$

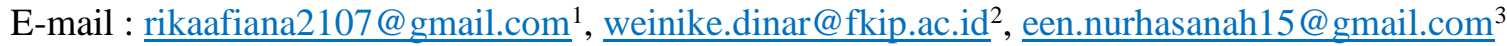

\begin{abstract}
Abstrak
Rendahnya nilai dan minat siswa dalam memahami bacaan di masa Pandemi COVID-19, sehingga penelitian ini bertujuan untuk mengetahui keefektifan metode SQ3R terhadap pembelajaran membaca pemahaman teks fiksi di masa pandemi covid-19 pada siswa SMP kelas VII. Metode yang digunakan dalam penelitian ini adalah kuantitatif deskriptif dengan jenis eksperimen dan desain penelitian one grup pretest-posttest desain, dengan teknik pengumpulan data melalui tes (pretest-posttest) dan non tes (observasi dan angket). Hasil penelitian menunjukan bahwa: (1) rata-rata hasil belajar siswa pada nilai posttest sebesar $78 \geq 75$ (KKM) dengan nilai (Sig $0.004<0.05$ ), memiliki persentase ketuntasan klaksikal $81 \% \geq 80 \%$ yang berada pada kategori tinggi, dengan nilai proporsi ketuntasan klaksikal (Sig $0.535>0.05$ ). (2) peningkatan nilai (gain ternormalisai) sebesar $0.53 \geq 0.3$ pada kategori sedang, dengan nilai (Sig $0.000<0.05$ ). (3) aktivitas siswa memiliki persentase keaktifan $84 \% \geq 60 \%$ pada kategori sangat aktif. (4) respons siswa memiliki persentase positif sebesar $87.4 \%>80 \%$ pada kategori positif, dengan nilai proporsi (Sig $0.107>0.05$ ). Berdasarkan kriterian keefektifan menunjukan bahwa semua aspek telah terpenuhi melebihi nilai minimum.
\end{abstract}

Kata Kunci: Metode SQ3R, Membaca Pemahaman, Teks fiksi, Pandemi COVID-19.

\section{Abstract}

The low value and interest of students in understanding reading during the COVID-19 Pandemic, so this study aims to determine the effectiveness of the SQ3R method regarding learning to read comprehension of fiction texts during the covid-19 pandemic in class VII students. The method used in this research is descriptive quantitative with experimental type and one group pretest-posttest research design, with data collection techniques through tests (pretest-posttest) and non-test (observation and questionnaires). The results showed that: (1) the average student learning outcomes at the posttest score of $78 \geq 75$ with a value (Sig $0.004<$ 0.05), had a classical mastery percentage of $81 \% \geq 80 \%$ which was in the high category, the proportion of classical completeness (Sig $0.535>0.05$ ). (2) an increase in value (normalized gain) of 0.530 .3 in the medium category, with a value (Sig $0.000<0.05$ ). (3) student activity has an active percentage of $84 \% 60 \%$ in the very active category. (4) student responses have a positive percentage of $87.4 \%>80 \%$ in the positive category, with a proportional value (Sig $0.107>0.05$ ). Based on the criteria of effectiveness, it shows that all aspects have been met, exceeding the minimum value.

Keywords: SQ3R Method, Reading Comprehension, Fiction Text, COVID-19 Pandemic.

Copyright (c) 2021 Rika Afiana, Wienike Dinar Pratiwi, Een Nurhasanah

$\triangle$ Corresponding author:

Email : rikaafiana2107@gmail.com

DOI : https://doi.org/10.31004/edukatif.v3i5.855

ISSN 2656-8063 (Media Cetak)

ISSN 2656-8071 (Media Online)

Edukatif : Jurnal Ilmu Pendidikan Vol 3 No 5 Tahun 2021 p-ISSN 2656-8063 e-ISSN 2656-8071 


\section{PENDAHULUAN}

Pandemi COVID-19 telah menimpa seluruh dunia, termasuk Indonesia. Sehingga karena adanya pandemi COVID-19 pemerintah membuat beberapa kebijakan berupaya menghentikan penyebaran virus ini diantaranya, membuat kebijakan Pembatasan Sosial Berskala Besar (PSBB). Karena adanya kebijakan tersebut, Menteri Pendidikan dan Kabudayaan Republik Indonesia membuat keputusan meliburkan siswa dan mulai menetapkan sitem pembelajaran jarak jauh secara daring. Berdasarkan surat edaran nomor 15 tahun 2020 tentang pedoman penyelenggaraan belajar dari rumah dalam masa darurat penyebaran COVID-19.

Menurut (Yunitasari \& Hanifah, 2020) pembelajaran harus tetap berlangsung, walaupun terjadi bencana pandemi global yang menjadikan pemerintah menerapkan social distancing pada dunia pendidikan. Solusi paling tepat dengan pandemi ini adalah pembelajaran jarak jauh secara daring. Pembelajaran daring menurut (Pratama \& Mulyati, 2020) adalah pembelajaran yang dilakukan tanpa melakukan tatap muka, tetapi melalui platformyang telah tersedia. Segala bentuk materi pelajaran didistribusikan secaraonline, komunikasi juga dilakukan secaraonline, dan tes juga dilaksanakan secaraonline.

Oleh karena itu guru harus inovatif dan kreatif dalam melakukan proses pembelajaran jarak jauh di masa pandemi COVID-19. Proses pembelajaan yang inovatif dan kreatif dapat meningkatkan kualitas pendidikan, sehingga diharapkan mampu memberikan bekal kepada siswa untuk menghadapi tantangan masa kini dan masa yang akan datang. Pembelajaran akan lebih inovatif jika melibatkan peserta didik dalam merencanakan, melaksanakan, dan mengevaluasi pembelajaran. Salah satu metode yang memungkinkan peserta didik aktif dalam pembelajaran jarak jauh adalah SQ3R (Survey, Question, Read, Recite, Review).

Alasan utama dalam penelitian ini adalah kurangnya daya tangkap siswa terhadap materi dan kurangnya minat siswa dalam membaca khususnya membaca fiksi di masa pandemi COVID-19, sehingga siswa belum mampu memahami bacaan dengan benar, dan siswa juga belum mampu menyampaikan kembali hasil bacaan yang mereka dapatkan dengan bahasa yang baik, benar dan runtun. Selain itu juga siswa kelas VII merupakan siswa peralihan dari Sekolah Dasar ke Sekolah Menengah, oleh karena itu siswa membutuhkan adaptasi yang baik agar mampu menyesuaikan dengan lingkungan dan suasana baru. Pada siswa kelas VII juga Informasi dan pengalaman belum terlalu banyak. Dengan demikian pengunaan metode pembelajaran dan pengolahan guru dalam proses pembelajaran jarak jauh akan sangat berpengaruh terhadap pemahaman dan perkembangan belajar siswa.

Selain itu dalam proses pembelajaran jarak jauh guru cenderung hanya memberikan tugas sehingga siswa merasa jenuh dalam pembelajaran dan dalam penggunaan metode pembelajaran yang digunakan juga kurang berfariatif, sehingga hasil belajar tidak maksimal karena proses pembelajaran jarak jauh terasa membosankan dan siswa sulit dalam memahami materi. Hal ini juga dibuktikan dari beberapa hasil penelitian mengenai pembelajaran di masa pandemi COVID-19 hasil dan motivasi siswa rendah, Menurut hasil penelitian yang dikemukakan oleh (Yunitasari \& Hanifah, 2020) menunjukkan bahwa pembelajaran daring pada masa pandemi COVID-19 sangat berpengaruh terhadap minat belajar siswa, siswa merasa bosan karena tidak bertemu dengan teman dan gurunya secara langsung. Selanjunya penelitian yang dilakukan (A'dadiyyah, 2021) yakni menurunnya hasil belajar atau hasilnya tidak mencapai KKM. Kemampuan siswa yang berhasil menyelesaikan soal tes itu hanya $36 \%$.

Dengan demikian penelitian ini menggunakan metode pembelajaran SQ3R yang diharapkan mampu dengan mudah memahamkan peserta didik dalam pembelajaran khusunya dalam hal membaca. Dimana siswa dituntut untuk memahami isi dari teks fiksi (Cerpen) yang dibacanya. Yaitu, siswa dapat menentukan struktur cerpen, unsur-unsur intrinsik dan ekstrinsik teks cerpen, dan memahami nilai yang terkandung di dalamnya. Penerapan metode pembelajaran ini juga membuat siswa rileks dan juga terarah saat melakukan pembelajaran sehingga meskipun pembelajaran dilakukan secara jarak jauh melalui aplikasi Google classroom dan WhatsApp, Google Meet, Zoom dan yang lannya agar siswa merasa tidak merasa bosan. Metode SQ3R ini 
melakukan aktivitas membaca yang sangat sistematis, sehingga diharapkan hasil belajar dan minat belajar siswa naik, dengan langkah-langkah yang sudah jelas dan terarah. Meskipun dilakukan jarak jauh penggunaan metode SQ3R diharapkan efektif dalam pembelajaran membaca pemahaman teks fiksi dan di masa pandemi COVID-19 pada siswa kelas VII .

Membaca merupakan kegiatan yang penting bagi seseorang dalam hal ini siswa sekolah dasar yang ingin meningkatkan diri untuk memperluas wawasannya pada jenjang SMP (Whesli et al., 2021). (Soleh, 2005) berpendapat selama ini cara membaca yang biasa dilakukan oleh peserta didik dengan membaca dari halaman awal sampai pada halaman akhir, dengan metode seperti itu, peserta didik merasa membaca membosankan danmenghabiskan banyak waktu. Menurut (Tarigan, 2015) membaca pemahaman (reading for understading) adalah jenis membaca untuk memahami standar-standar atau norma kesastraan, resensi kritis, drama tulis, dan pola-pola fiksi dalam usaha memperoleh pemahaman terhadap teks, pembaca menggunakan strategi tertentu. Pemilihan strategi berkaitan erat dengan faktor-faktor yang terlibat dalam pemahaman, yaitu pembaca teks dan konteks. Membaca pemahaman adalah kegiatan membaca yang dilakukan dengan hati-hati dan sangat telitih, juga dilakukan secara sungguh-sungguh sehingga mengerti dan memahami isi atau maksud dari bacaan. Dengan membaca kita bisa mendapatkan informasi apa saja yang kita cari dan informasi apa saja yang sedang terjadi (Sukirno, 2009). Berdasarkan pendapat para ahli di atas mengenai membaca pemahaman, dapat disimpulkan bahwa membaca pemahaman adalah merupakan keterampilan membaca yang tinggi, guna mendapatkan informasi secara detail dan akurat dari bacaan yang mereka baca.

Buku fiksi adalah karya tulis berupa karya imajinasi berdasarkan khayalan belaka. Fiksi adalah cabang dari ilmu sastra yang menyusun karya-karya narasi imajinatif. Bentuk buku fiksi berupa novel, novellet, roman, cerpen, drama, puisi, pantun dan syair (Muhammad Yusuf, 2005). Cerpen merupakan salah satu ragam fiksi atau cerita rekaan yang sering disebut kisahan prosa pendek. Cerpen adalah karangan pendek berbentuk prosa yang dibentuk oleh beberapa komponen, yakni tema, alur, latar, penokohan, sudut pandang, amanat, dan gaya bahasa. Jadi, cerpen adalah karya fiksi berupa prosa dengan mengungkapkan satu permasalahan yang ditulis secara singkat dan padat yang dibentuk oleh beberapa komponen, yakni tema, alur, latar, penokohan, sudut pandang, amanat, dan gaya bahasa (Kosasih, 2012). Maka dapat disimpulkan bahwa teks fiksi adalah cerita rekaan yang berasal dari khayalan pengarang, cerita fiksi mampu menggugah emosi pembaca yang disampaikan melalui kata-kata yang dibuat oleh pengarang. cerpen merupakan karya sastra yang berbentuk naratif, jumlah kata dalam cerpen hanya 1000-5000 kata, sehingga membacanya bisa dilakukan dalam waktu singkat atau dapat dibaca sekali duduk, cerpen memiliki satu atur dan satu konfik dalam ceritanya. Cerpen juga memiliki nilai-nilai seperti nilai agama, nilai moral, dan nilai budaya.

Menurut Syah, 2003:130 dalam (Prastiwi, 2017). Metode SQ3R merupakan metode yang dikembangkan oleh Francis P. Robinson dari Ohio University pada tahun 1941. Metode SQ3R merupakan singkatan dari setiap langkah-langkah yang dilakukan dalam kegiatan membaca meliputi langkah survey, question, read, recite, dan review. Metode SQ3R adalah metode pembelajaran memiliki langkah-langkah yang sistematis dan juga terarah untuk memudahkan siswa dalam memahami bacaan.

Menurut (Usman, 2015) Dalam proses pembelajaran ketrampilan membaca pemahaman, metode yang melakukan tahapan yang beraturan salah satu adalah metode SQ3R. Metode ini terdiri dari lima tahap yaitu Survey, Question, Read, Recite, Review (SQ3R). Langkah pertama suvey, siswa melakukan observasi untuk mengetahui gambaran isi dalam teks yang akan dibaca.. Langkah kedua, question siswa membuat beberapa pertanyaan terhadap teks yang akan dibacanya. Langkah ketiga, read pada tahap ini siswa membaca secara aktif membaca teks untuk menemukan jawaban dari pertanyaan yang sudah dibuat. Keempat, tahap recite siswa meninjau ulang bacaanya untuk memastikan jawaban dari pertanyaanya sudah benar, sehingga siswa benar-benar memahami teks yang telah dibacanya. Langkah terakhir atau kelima, adalah review siswa mempersentasikan hasil bacaan dari teks yang telah dibaca.. Tahapan-tahapan Metode SQ3R ini diharapkan dapat mengatasi permasalahan rendahnya kemampuan membaca pemahaman siswa. 
Beberapa penelitian terkait penerapan metode SQ3R dalam pembelajaran adalah penelitian yang dilakukan oleh (Emilda, 2020) penelitian ini sama-sama menggunakan metode SQ3R, dan sama-sama dalam aspek keterampilan membaca. penelitian ini juga sama-sama menggunakan jenis penelitian eksperimen. Perbedaanya penelitian yang dilakukan oleh Ilham dilakukan secara tatap muka, dengan objek penelitian siswa-siswa SMK. Sedangkan Penelitian ini dilakukan dengan pembelajaran jarak jauh menggunakan beberapa aplikasi seperti WhatsApp, Google Clasroom, Zoom dan yang lainnya, agar pembelajaran dapat terlaksana dengan semestinya, dengan objek penelitian siswa siswi Sekolah Menengah Pertama. Selanjutnya adalah relevansi antara penelitian yang digunakan oleh (Apriliani, 2019) adalah penelitian ini sama-sama menggunakan metode SQ3R, dan sama-sama dalam aspek keterampilan membaca pemahaman. Perbedaanya penelitian yang dilakukan oleh Apriliani dilakukan secara tatap muka, dengan objek penelitian siswa-siswa Sekolah Dasar sedangkan objek penelitian ini adalah siswa-siswi Sekolah Menengah Pertama. Selain itu juga jenis penelitian yang digunakan Apriliani adalah Penelitan Tindakan Kelas (PTK) sedangkan peneliti menggunakan penelitian jenis eksperimen.

Berdasarkan penelitian-penelitian yang relevan di atas, maka dapat disimpulkan bahwa perbedaan penelitian ini dengan penelitian lainnya adalah terletak pada jenis penelitian, subjek penelitian. Dan yang paling membedakan adalah proses penelitian ini tidak dilakukan secara tatap muka melainkan dilakukan proses pembelajaran secara jarak jauh secara daring melalui berbagai aplikasi yang dapat digunakan untuk pembelajaran dimasa pandemi COVID-19. Sehingga hasil dari penelitian ini diharapkan mampu menambah pengetahuan kepada pembaca khususnya bagi pendidik dan calon pendidik dalam penerapan metode pembelajaran SQ3R menggunakan aplikasi dalam pembelajaran jarak jauh dimasa pandemi COVID-19. Agar penerapan metode pembelajaran lebih berfariatif dan siswa tidak merasa bosan saat proses pembelajaran berlangsung, sehingga siswa memiliki semangat dalam belajar dan hasil pembelajaran siswa juga dapat maksimal.

\section{METODE PENELITIAN}

Berdasarkan tujuan penelitian, metode yang digunakan dalam penelitian ini adalah metode kuantitatif . Metode ini dipilih karena sesuai dengan karakteristik tujuan penelitian. Menurut (Sugiyono, 2016) metode penelitian kuantitatif diartikan sebagai penelitian yaang berlandaskan pada filsafah positivisme, dengan pengumpulan data menggunakan instrumen penelitian, analisis bersifat kuantitatif/statistik dengan tujuan untuk menguji hipotesis. Dalam penelitian ini juga menggunakan jenis penelitian eksperimen, penelitian eksperimen adalah penelitian yang digunakan untuk mencari pengaruh perlakuan tertentu terhadap yang lain dalam kondisi yang terkendali, kondisi yang terkendali dimaksud adalah adanya hasil dari penelitian dikonversikan ke dalam angka-angka untuk analisis yang digunakan dengan menggunakan analisis statistik (Sugiyono, 2010) . Pada metode penelitian ini bentuk eksperimen yang digunakan adalah One-Group PretestPosttes Design. Hal ini dilakukan untuk mencari perbedaan nilai $O_{2}-O_{1}$. Tujuan penelitian ini adalah untuk menyelidiki adakah pengaruh metode SQ3R terhadap keterampilan membaca pemahaman teks fiksi siswa kelas VII F SMP Negeri 3 Jatibarang di masa pandemi COVID-19.

Adapun Populasi penelitian ini adalah siswa kelas VII SMP Negeri 3 Jatibarang, yang terdiri dari 9 kelas, yaitu kelas VII A, VII B, VII C, VII D, VII E, dan VII F. VII G, VII I, yang setiap kelas terdapat 32 peserta didik. Sampel penelitian ini adalah kelas eksperimen pada siswa kelas VII F dengan jumlah 32 peserta didik. Instrumen penelitian ini adalah tes (pretest-posttest) tes digunakan untuk mengukur kemampuan dasar maupun pencapaian dengan memberikan soal 20 pilihan ganda. Instrumen tes disini yang pertama adalah pretest bertujuan untuk mengetahui sejauh mana pengetahuan dan pemahaman siswa mengenai materi yang akan dibahas. Lalu posttest bertujuan untuk mengtahui apakah semua materi dapat dikuasai dengan baik, sehingga tes akhir ini berfokus kepada hasil dan peningkatan belajar yang didapat oleh siswa. Selanjutnya untuk instrumen non-tes (observasi dan angket), observasi dilakukan saat proses pembelajaran berlangsung 
untuk melihat aktivitas siswa saat diberikan perlakuan. Angket diberikan sesudah perlakuan untuk mengetahui respons siswa seletah menggunakan metode SQ3R dalam pembelajaran jarak jauh di masa pandemi COVID19. Untuk teknik analisis data menggunakan teknik analisis data Deskriptif dan analisis data Statistic.

\section{HASIL DAN PEMBAHASAN PENELITIAN}

Analisis penelitian ini digunakan untuk mengetahui apakah metode SQ3R efektif dalam pembelajaran membaca pemahaman teks fiksi pada siswa kelas VII di masa pandemi COVID-19, dengen memenuhi krteria keefektifan rata-rata hasil belajar posttest, ketuntasan klaksikal, peningkatan nilai (gain ternormalisasi), aktivitas, dan respons siswa.

\section{Nilai rata-rata posttest dan ketuntasan klaksikal}

Hasil penelitian ini adalah siswa memiliki rata-rata nilai pada pretest sebesar 49 dalam artian nilai pretest kurang dari KKM, sedangkan untuk rata-rata nilai posttest yaitu sebesar 78 melebihi nilai KKM yakni 75, sehingga rata-rata nilai siswa pada posttest memenuhi kriteria berada pada kategori sedang. Untuk ketuntasan klaksikal pada posttest siswa memiliki persentase $81 \%$.

Tabel 1

Data Ketuntasan Klaksikal Hasil Belajar

\begin{tabular}{lccc}
\hline \multicolumn{1}{c}{ Tes } & KKM & Tuntas & Tidak Tuntas \\
\hline Pretest & 75 & $16 \%$ & $84 \%$ \\
Posttest & & $81 \%$ & $19 \%$ \\
\hline
\end{tabular}

Berdasarkan tabel 1. Hasil ketuntasan klaksikal siswa dengan nilai $\mathrm{KKM} \geq 75$, dapat kita lihat bahwa pada pretest untuk persentase ketuntasan siswa hanya 16\%, dalam artian hasil belajar siswa masih sangat rendah. Sedangkan pada posttest persentase ketuntasan siswa mencapai $81 \%$ dalam artian hasil belajar siswa tinggi. Untuk nilai signifikansi posttes memiliki nilai sebesar 0.004 , maka hasil data tersebut menunjukan bahwa nilai sig. $<0.05$. dengan hipotesis nilai sig. $<0.05$, maka $\mathrm{H}_{1}$ diterima dan $\mathrm{H}_{0}$ ditolak.

Hal ini dikarenakan penggunaan metode SQ3R adalah metode yang membuat peserta didik memahami bacaan karena lebih terstruktur dalam membaca. Dengan langkah pertama siswa melakukan survey, untuk membaca sekilas mengetahui susunan bacaan, bahan bacaan atau materi ajar teks fiksi diambil dari Wattpad karya Agustin Azzahra dalam kumpulan cerpen pendidikan. Langkah selanjutnya adalah question, siswa membuat pertanyaan-pertanyaan mengenai isi dari bacaan seperti membuat pertanyaan-pertanyaan mengenai unsur-unsur dari bacaan tersebut. Lalu pada langkah ketiga adalah read, yakni siswa diarahkan untuk membaca dengan aktif dengan serius/sungguh-sungguh dari bahan bacaan yang didapat. Langkah selanjutnya adalah siswa mencari jawaban atas pertanyaan-pertanyaan yang sebelumnya telah dibuat. Dan pada tahap terakhir ialah riview, yaitu siswa mempersentasikan hasil bacaan yang telah dibuat, persentasi ini mengunakan aplikasi zoom.

\section{Peningkatan nilai (gain ternormalisasi)}

Berdasarkan nilai hasil belajar peserta didik yang telah dilakukan sebelum dan setelah menggunakan metode SQ3R, maka diketahui bahwa memiliki rata-rata nilai gain ternormalisasi sebesar 0,53 yang berarti berada pada klasifikasi sedang. Klasifikasi peningkatan hasil peserta didik dapat dilihat pada tabel klasifikasi nilai gain ternormalisasi berikut ini

Tabel 2

Klasifikasi Nilai Gain Ternormalisasi

\begin{tabular}{c|cccc}
\hline $\begin{array}{c}\text { Keefisien gain } \\
\text { ternormalisasi }\end{array}$ & Jumlah siswa & Persentase & Klasifikasi \\
\hline $\mathrm{g}<0.3$ & 4 & $12 \%$ & Rendah \\
$0.3 \leq \mathrm{g}<0.7$ & 22 & $69 \%$ & Sedang
\end{tabular}


2367 Keefektifan Metode SQ3R dalam Pembelajaran Membaca Pemahaman Teks Fiksi di Masa Pandemi Covid-19 pada Siswa SMP - Rika Afiana, Wienike Dinar Pratiwi, Een Nurhasanah

DOI: https://doi.org/10.31004/edukatif.v3i5.855

\begin{tabular}{|c|c|c|c|}
\hline $\mathrm{g} \geq 7$ & 6 & $19 \%$ & Tinggi \\
\hline Jumlah & & 100 & \\
\hline Rata-rata & 0,53 & & Sedang \\
\hline
\end{tabular}

Pada tabel 2. dapat kita ketahui bahwa terdapat 4 siswa yang memilik peningkatan rendah $g<0.3$ dengan persentase $12 \%$. Dan terdapat 22 siswa memiliki peningkatan pada kategori sedang $0.3 \geq \mathrm{g}<0.7$ dengan persentase sebesar $69 \%$. Lalu terdapat 6 siswa memiliki peningkatan $g \geq 7$ memiliki persentase sebesar 19\%, dengan kalsifikasi tinggi. Untuk nilai signifikansi gain ternormalisasi memiliki nilai 0.000, maka hasil data tersebut menunjukan bahwa nilai sig. $<0.05$. Dengan hipotesis nilai sig. $<0.05$, maka $\mathrm{H}_{1}$ diterima dan $\mathrm{H}_{0}$ ditolak, sehingga dapat disimpulkan bahwa metode SQ3R efektif dalam pembelajaran membaca pemahaman siswa kelas VII dimasa pandemi COVID-19.

\section{Aktivitas siswa}

Untuk aspek kriteria keefektifan selanjutnya adalah data hasil analisis aktivitas siswa yang diperoleh dengan melakukan observasi secara langsung saat proses pembelajaran di masa pandemi covid-19 menggunakan metode SQ3R. Dengan sistem pembelajaran jarak jauh yang memanfaatkan beberapa aplikasi yang dapat digunakan sebagai media pembelajaran, agar proses pembelajaran dapat terlaksana dengan semestinya.

\section{Tabel 3}

\begin{tabular}{cccccccc} 
Aktivitas Siswa Saat Pembelajaran Daring di Masa Pandemi Covid-19 \\
\cline { 2 - 6 } No & \multicolumn{4}{c}{ Pertemuan } & \multicolumn{1}{c}{ Rata- } \\
\cline { 2 - 6 } & $\mathbf{1}$ & $\mathbf{2}$ & $\mathbf{3}$ & $\mathbf{4}$ & Persentase \\
\hline $\mathbf{1}$ & 3 & 4 & 5 & 4 & 4 & $80 \%$ \\
$\mathbf{2}$ & 3 & 4 & 5 & 5 & 4.25 & $85 \%$ \\
$\mathbf{3}$ & 4 & 3 & 5 & 4 & 4 & $80 \%$ \\
$\mathbf{4}$ & 4 & 4 & 4 & 5 & 4.25 & $85 \%$ \\
$\mathbf{5}$ & 4 & 4 & 5 & 5 & 4.5 & $90 \%$
\end{tabular}

\begin{tabular}{lllllll}
\hline Jumlah & 18 & 19 & 24 & 23 & 21 & $84 \%$
\end{tabular}

Berdasarkan kritera keefektifan aktivitas siswa minimal berada pada persentase $60 \%$ pada kategori cukup. Sedangkan dalam penelitian ini, dapat kita lihat pada tebel tersebut, kita ketahui bahwa setiap pertemuan siswa memiliki persentase keaktifan mencapai $\geq 80 \%$, dengan persentase rata-rata keseluruhan $84 \%$ dengan artian berada pada kategori sangat aktif.

Hasil pengamatan aktivitas siswa menggunakan metode SQ3R dimasa pandemi sangat berpengaruh untuk keaktifan siswa. Dalam pembelajaran sebelumnya yang hanya memberikan penugasan membuat siswa pasif sehingga hanya terfokus dalam penugasan tanpa melibatkan siswa dalam proses pembelajaran. Penggunan metode SQ3R yang memilihi tahapan jelas dan terarah sehingga melibatkan siswa secara aktif meskipun dilakukan pembelajaran jarak jauh dimasa pandemi COVID-19. Dengan menggunakan metode SQ3R menjadi lebih optimal, mulai dari penjelasan materi yang diberikan melalui powerpoint lalu teks fiksi (cerpen) sebagai bacaan atau bahan ajar untuk siswa menyelsaikan permasalahan. Dalam pembelajaran ini siswa diberikan kesempatan untuk membuat pertanyan-pertanyaan dan menjawab pertanyaan yang telah dibuatnya lalu mengulasnya dengan guru, sehingga siswa memilihi tanggung jawab dalam pembelajaran 
2368 Keefektifan Metode SQ3R dalam Pembelajaran Membaca Pemahaman Teks Fiksi di Masa Pandemi Covid-19 pada Siswa SMP - Rika Afiana, Wienike Dinar Pratiwi, Een Nurhasanah

DOI: https://doi.org/10.31004/edukatif.v3i5.855

\section{Respons siswa}

Untuk kriteria keefektifan yang terakhir adalah hasil analisis respons siswa seletah menggunakan metode SQ3R sehingga dapat dikatakan efektif pada pembelajaran jarak jauh dimasa pandemi COVID-19, jika persentase respons siswa positif setelah menggunakan metode SQ3R berada pada persentase $80 \%$.

Tabel 4

Kuisioner Respons Siswa

\begin{tabular}{ccc}
\hline \multirow{2}{*}{ No } & \multicolumn{2}{c}{ Respon Siswa } \\
\cline { 2 - 3 } & Ya & Tidak \\
\hline 1 & $84.4 \%$ & $15.6 \%$ \\
2 & $87.5 \%$ & $12.5 \%$ \\
3 & $84.4 \%$ & $15.6 \%$ \\
4 & $87.5 \%$ & $12.5 \%$ \\
5 & $87.5 \%$ & $12.5 \%$ \\
6 & $87.5 \%$ & $12.5 \%$ \\
7 & $87.5 \%$ & $12.5 \%$ \\
8 & $84.4 \%$ & $15.6 \%$ \\
9 & $90.6 \%$ & $9.4 \%$ \\
10 & $87.5 \%$ & $12.5 \%$ \\
\hline Rata-rata & $87.4 \%$ & $12.6 \%$ \\
\hline
\end{tabular}

Dalam penelitian ini untuk kategori respons siswa positif memiliki rata-rata persentase $87.4 \%$ sehingga berada pada kategori positif. Persentase tertinggi sebesar 90,6\%, sedangkan terendah dengan persentase 84.4\%. Untuk nilai proporsi respons siswa, memiliki nilai signifikansi sebesar 0.107 nilai tersebut menunjukan bahwa nilai sig. > 0.05. 0. Dengan hipotesis nilai sig. $>0.05$ maka $\mathrm{H}_{1}$ diterima dan $\mathrm{H}_{0}$ ditolak.

Yang berarti penggunaan metode SQ3R mampu memahami siswa dalam memahami materi, siswa juga lebih termotivasi aktif dalam pembelajaran. Dan siswa memiliki interaksi yang baik dengan teman sekelasnya saat menggunakan metode SQ3R dalam pembelajaran. Lalu siswa juga lebih aktif interaksi dengan guru meskipun pembelajaran dilakukan secara jarak jauh karena pandemi COVID-19. Selanjutnya pada aspek ke delapan siswa lebih aktif dalam berbpendapat dan bertanya pada saat pembelajaran dengan persentase postif 84.4\%. Lalu pada aspek ke sembilan tanggapan siswa terhadap pembelajaran yang diterapkan guru memiliki persentase positif paling tinggi dengan nilai persentase 90.6\%. Dan pada aspek terakhir mengenai tanggapan siswa terhadap penggunaan metode SQ3R yang akan diterapkan dipembelajaran selanjutnya memiliki persentase $87.5 \%$.

Beberapa penelitih menunjukan terdapat peningkatan pada keterampilan membaca pemahaman siswa menggunakan motode SQ3R. Seperti pada penelitian yang dilakukan (Sobri, 2017) menunjukan bahwa metode SQ3R dapat meningkatkan pemahaman bacaan siswa, peningkatan komunikasi siswa , dan peningkatan hasil rata-rata membaca bahasa indonesia pada siswa. Selanjutnya pada penelitian (Ilmi et al., 2017) didapatkan Hasil penilaian terhadap kemampuan siswa nilai rata-rata pada siklus I sebesar 63. Meningkat pada siklus II yaitu 77 dan pada siklus III 88. Sedangkan ketuntasan belajarkelas untuk siklus I yaitu $31 \%$, pada siklus II $69 \%$, serta meningkat padasiklus III yaitu $88 \%$.

Berdasarkan hasil dari beberapa penelitian yang menerapkan metode SQ3R dalam proses pembelajaran, baik dilakukan tatap muka maupun jarak jauh secara daring khususnya pada keterampilan membaca, penelitih setuju bahwa metode SQ3R dapat meningkatkan kemampuan membaca pemahaman peserta didik dan mampu membuat peserta didik lebih aktif dalam proses pembelajaran, sehingga penggunaan metode SQ3R bisa dijadikan alternatif yang diterapkan oleh guru dalam pembelajaran agar proses pembelajaran lebih bervariatif dan inovatif. 
2369 Keefektifan Metode SQ3R dalam Pembelajaran Membaca Pemahaman Teks Fiksi di Masa Pandemi Covid-19 pada Siswa SMP - Rika Afiana, Wienike Dinar Pratiwi, Een Nurhasanah

DOI: https://doi.org/10.31004/edukatif.v3i5.855

\section{KESIMPULAN}

Berdasarkan hasil penelitian yang telah diperoleh sebelumnya, tentang keefektifan metode SQ3R dalam pembelajaran membaca pemahaman teks fiksi pada siswa kelas VII SMP Negeri 3 Jatibarang di masa pandemi COVID-19. Dengan beberap kriteria keefektifan, maka penelitih menyimpulkan hasil penelitian sebagai berikut: 1) Rata-rata nilai siswa sebelum menggunakan metode SQ3R sebesar 47 yang berarti memiliki kategori yang masih sangat rendah, lalu setelah menggunakan metode SQ3R nilai rara-rata siswa sebesar 78 dengan kategori sedang. 2) Peningkatan nilai sebelum dan sesudah perlakuan menggunakan metode SQ3R siswa memiliki rata-rata peningkatan sebesar 0.57 dengan kategori sedang. 3) Selanjutnya untuk kategori ketuntasan klaksikal siswa pada pretest atau sebelum perlakuan memiliki persentase ketuntasan hanya $16 \%$, sedangkan setelah pertakuan atau posttest memiliki persentase ketuntasan sebesar $81 \%$. 4) Pada kriteria keefektifan ke empat adalah aktivitas siswa saat proses pembelajaran berlangsung menggunakan metode SQ3R yang dilakukan selama empat pertemuan secara jarak jauh melalui berbagai aplikasi memiliki persentase sebesar $84 \%$. 5) Lalu pada kriteria keefektifan yang terakhir adalah respons siswa dengan respons postif terhadap penggunaan metode SQ3R yang diterapkan di proses pembelajaran memiliki persentase sebesar $87.4 \%$. Sehingga dapat disimpulkan bahwa metode SQ3R efektif dalam pembelajaran membaca pemahaman siswa kelas VII dimasa pandemi COVID-19.

\section{UCAPAN TERIMA KASIH}

Puji dan syukur saya panjatkan atas rahmat dan karunia Allah SWT, dan saya ucapkan terima kasih kepada semua pihak yang membantu kelancaran penelitian ini, Kepada kedua orang tua yang selalu memberikan semangat dan doa, teman-teman, dosen pembimbing, pihak-pihak SMP Negeri 3 Jatibarang.

\section{DAFTAR PUSTAKA}

A'dadiyyah, N. L. (2021). Dampak Pembelajaran Daring Terhadap Hasil Belajar Matematika Siswa Kelas V MI NU Wasilatut Taqwa Kudus Tahun 2020/2021. Laplace: Jurnal Pendidikan Matematika, 4(1), 4049. https://doi.org/10.31537/laplace.v4i1.462

Apriliani, I. N. (2019). Penerapan Metode Sq3R Untuk Meningkatkan Kemampuan Membaca Pemahaman Siswa Kelas IV Sekolah Dasar. PENDIDIKAN GURU SEKOLAH DASAR, 2007, 1-2.

Emilda, S. A. dan. (2020). Pengaruh SQ3R dalam Meningkatkan Kemampuan Membaca Siswa. http://journal.stainkudus.ac.id/index.php/equilibrium/article/view/1268/1127\%0Ahttp://publicacoes.card iol.br/portal/ijcs/portugues/2018/v3103/pdf/3103009.pdf\%0Ahttp://www.scielo.org.co/scielo.php?script $=$ sci_arttext\&pid=S0121-75772018000200067\&lng=en\&tlng=

Ilmi, D. N., Hermawan, R., \& Riyadi, A. R. (2017). Metode Pembelajaran Sq3R Untuk Meningkatkan Kemampuan Membaca Pemahaman. Jurnal Pendidikan Guru Sekolah Dasar, 2(4), 88-99. https://doi.org/10.17509/jpgsd.v2i4.14009

Kosasih, E. (2012). Dasar-dasar Keterampilan Bersastra. Yrama Widya.

Muhammad Yusuf. (2005). Pedoman Penyelenggaraan Perpustakaan Sekolah. Kencana.

Prastiwi, L. (2017). the Improvement of Reading Comprehension on Sq3R. Jurnal Widia Ortodidaktika, 6, $620-628$.

Pratama, R. E., \& Mulyati, S. (2020). Pembelajaran Daring dan Luring pada Masa Pandemi Covid-19. Gagasan Pendidikan Indonesia, 1(2), 49. https://doi.org/10.30870/gpi.v1i2.9405

Sobri. (2017). Strategi Belajar Sq3r (Survey, Question, Read, Recite, Review) dalam Upaya Peningkatan Pemahaman Bacaan Siswa. Journal of Language Learning and Research (JOLLAR), 1(1), 57-75. https://doi.org/10.22236/JOLLAR

Soleh, K. (2005). Perbandingan Kemampuan Membaca Siswa SMA Berpola Asuh Otoriter dan Demokratis 
2370 Keefektifan Metode SQ3R dalam Pembelajaran Membaca Pemahaman Teks Fiksi di Masa Pandemi Covid-19 pada Siswa SMP - Rika Afiana, Wienike Dinar Pratiwi, Een Nurhasanah

DOI: https://doi.org/10.31004/edukatif.v3i5.855

Antara yang Diajar dengan SQ3R dan PQRST. Kajian Linguistik Dan Sastra, 17(33), 183-186.

Sugiyono. (2010). Statistik Untuk Penelitian. Alfabeth.

Sugiyono. (2016). Metode Penelitian Pendidikan Pendekatan Kuantitatif, Kualitatif, dan R\&D. Alfabeth.

Sukirno. (2009). Sistem Membaca Pemahaman Yang Efektif. UMP PRESS.

Tarigan, H. G. (2015). Membaca Sebagai Suatu Keterampilan Berbahasa. Angkasa.

Usman, R. (2015). Penggunaan Metode Sq3R Dan Motivasi Belajar Terhadap Hasil Belajar Membaca Pemahamaman Siswa Kelas Xi Sma Negeri 12 Pekanbaru. Primary: Jurnal Pendidikan Guru Sekolah Dasar, 4(2), 105. https://doi.org/10.33578/jpfkip.v4i2.2944

Whesli, H., Tyas, A., Hardini, A., Kristen, U., \& Wacana, S. (2021). EDUKATIF : JURNAL ILMU PENDIDIKAN Peningkatan Hasil Belajar IPA dengan Discovery Learning Berbantuan Media Audio Visual di Sekolah Dasar. 3(3), 698-704.

Yunitasari, R., \& Hanifah, U. (2020). Pengaruh Pembelajaran Daring terhadap Minat Belajar Siswa pada Masa COVID 19. Edukatif: Jurnal Ilmu Pendidikan, 2(3), 232-243.

https://doi.org/10.31004/edukatif.v2i3.142 